\title{
Thermochemical processes for biofuels production from biomass
}

\author{
Nicholas Canabarro, Juliana F Soares, Chayene G Anchieta, Camila S Kelling and Marcio A Mazutti ${ }^{*}$
}

\begin{abstract}
The contribution of biomass to the world's energy supply is presently estimated to be around $10 \%$ to $14 \%$. The conversion of biomass to biofuels can be achieved primarily via biochemical and thermochemical processes. Recently, the use of thermochemical processes as pyrolysis and gasification has received great attention. The biomass composition and form of process conduction can affect greatly the efficiency of conversion for both gasification and pyrolysis. This review compiles recent thermochemical studies using several kinds of biomass to obtain biofuels and, additionally, it presents a brief description of main gasification and pyrolysis processes employed. Publications in Patent database also were reported and compiled.
\end{abstract}

Keywords: Gasification, Pyrolysis, Biofuels, Biomass, Thermochemical processes

\section{Introduction}

Recently there has been a renewed interest in using biomass as an energy source due to the increasing demand in global energy coupled with environmental concerns of using fossil fuels. The contribution of biomass to the world's energy supply is presently estimated to be around $10 \%$ to $14 \%$ [1]. The conversion of biomass to biofuels can be achieved primarily via biochemical and thermochemical processes. The thermochemical processes can convert both food and nonfood biomass to fuel products via pyrolysis and gasification [2]. Thermochemical gasification is a promising technology that can exploit the embedded energy in various types of biomass and convert to valuable products suitable for different industrial applications. Common feedstock for gasification includes agricultural crop residues, forest residues, energy crops, organic municipal wastes, and animal waste $[2,3]$.

Pyrolysis, like gasification, is an advanced thermal treatment that converts a material into a syngas but at lower temperatures and in the absence of oxygen. It is always also the first step in combustion and gasification processes where it is followed by total or partial oxidation of the primary products [4,5]. Despite the calorific value of a gas derived from pyrolysis being higher than that of gasification, the volume of gas

\footnotetext{
* Correspondence: mazutti@ufsm.br

Department of Chemical Engineering, Federal University of Santa Maria, Av. Roraima, 1000, Santa Maria 97105-900, Brazil
}

produced is usually much lower due to the lack of the oxygen carrier [6-8].

Both pyrolysis and gasification of biomass are complex processes and depends on several factors such as the composition of lignocellulosic material, heating rate and content of inorganic material etc. The amounts of cellulose, hemicellulose and lignin present in the biomass affect the pyrolysis and gasification, implying in great variation in the efficiency among different biomass and process employed. In this sense, the objective of this review is to compile the main biomass used in thermochemical studies. In addition, it will be presented a brief description of main gasification and pyrolysis processes employed as well as the main technologies cited in patent database.

\section{Gasification}

In the gasification process, biomass is converted into a syngas by the partial oxidation of biomass at high temperatures [9]. Gasification takes place at moderately high temperature and turns solid biomass into combustible gas mixtures (known as synthesis gas or syngas) through simultaneous occurrence of exothermic oxidation and endothermic pyrolysis under limited oxygen supply $[2,10]$. The main components of this gas are $\mathrm{CO}, \mathrm{H}_{2}, \mathrm{CO}_{2}, \mathrm{CH}_{4}$, $\mathrm{H}_{2} \mathrm{O}$ and $\mathrm{N}_{2}$. However a variety of tars are also produced during the gasification reaction $[11,12]$. The resulting syngas can be burned to produce heat or synthesized to produce liquid transportation fuels $[2,13]$. Figure 1 shows a 


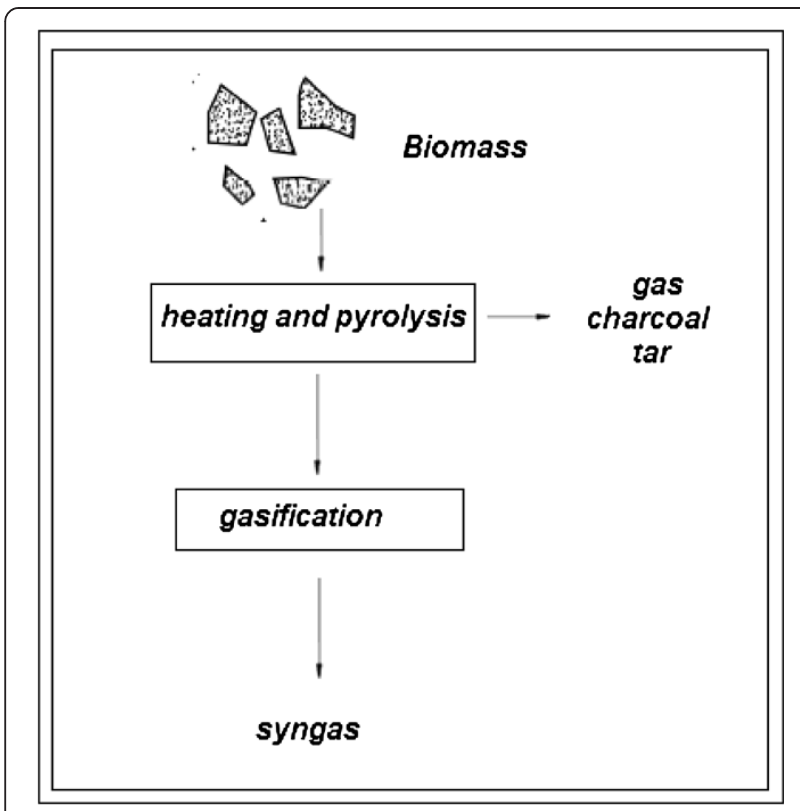

Figure 1 Schematic diagram for biomass gasification. density, which results in bubble coalescence within the bed and in turn a poor fluidization quality. Therefore, some inert particles (such as silica sand) are added as lubricants to facilitate the fluidization of biomass particles, or natural/artificial catalysts (such as dolomite, olivine, alkali-based catalyst, and metal-based catalyst). These particulates are introduced to improve fluidization quality and to reduce tars in the downstream process. Moreover, these gasifiers are usually equipped with cyclones to remove relatively fine particulates from the raw product gas. Depending on the fluidization pattern and combination character, these gasifiers can be further classified as bubbling fluidized bed, circulating fluidized bed, as showed in Figure 2, and double fluidized bed system. Fluidized bed gasifiers typically operate at temperatures of $800-1000^{\circ} \mathrm{C}$ to prevent ash from building up. Another advantage of this type of gasifier is that its high thermal inertia and vigorous mixing enables it to gasify different types of fuel, e.g. different types of biomass. This is therefore one of the preferred technologies for large-scale biomass gasification plants $[10,17,22,28,29]$.

\section{Dual fluidized bed gasification (DFB)}

The DFB gasifier consists of two reactors, where gasification and combustion take place separately [14]. Circulating bed material between these two reactors carries the heat from the combustion reactor to the gasification reactor [17]. In the DFB gasifier, biomass is gasified with steam. Due to steam gasification, there is virtually no nitrogen in the producer gas and the hydrogen content amounts to about $40 \%$. The average heating value is around $12-14 \mathrm{MJ} / \mathrm{Nm}^{3} \quad\left(\mathrm{Nm}^{3}=\right.$ at $273.15 \mathrm{~K}$ and 101.325 Pa, referred to as dry gas). Producer gas from steam gasification is well suitable not only for heat and electricity production, but also for chemical synthesis [14].

\section{Fixed bed gasification}

The fluidized bed (FB) provides high mixing and reaction rates, accommodates variation in fuel quality and allows scaling-up of the process. Various concepts have been developed for gasification in FB [31]. In fixed-bed gasifiers, the gas passes through the raw material while the gasifier zones are in "fixed" position where the reactions take place. Depending on the direction of gas flow, these gasifiers can be further classified as updraft, downdraft and cross-flow fixed beds showed in Figure 3 [22].

\section{Supercritical water gasification (SCWG)}

This process has the potential to convert biomass with water contents up to $80 \%$ directly without the need for an energy-expensive drying step [20]. An advantage of processing wet biomass hydrothermally, rather than drying it, is that doing so avoids the energy penalty dion and better solid-gas contact and heat tran rates. Compared with coal, biomass has lower particle 
Table 1 Comparison of different types of biomass and gasification process

\begin{tabular}{|c|c|c|}
\hline Process & Biomass & Experimental conditions \\
\hline \multirow{7}{*}{$\begin{array}{l}\text { Dual fluidized } \\
\text { bed gasifier }\end{array}$} & \multirow[t]{3}{*}{ Lignite } & Input fuel power: $90 \mathrm{~kW}_{\text {thi }}$ \\
\hline & & Particle size: 370 and $510 \mu \mathrm{m}$; \\
\hline & & $\begin{array}{l}\text { Steam-to-carbon ratio: } 1.3 \\
\text { and } 2.1 \mathrm{Kg}_{\mathrm{H} 2 \mathrm{O}} / \mathrm{Kg}_{\text {carbon. }}\end{array}$ \\
\hline & \multirow[t]{2}{*}{$\begin{array}{l}\text { Waste wood; Bark; } \\
\text { Plastic residues }\end{array}$} & $\begin{array}{l}\text { Input fuel power: } 100 \mathrm{~kW} \text {; } \\
\text { Nitrogen content: } 0.05 \text { to } \\
2.70 \text { wt.-\%. Temperature: } 850^{\circ} \mathrm{C}\end{array}$ \\
\hline & & $\begin{array}{c}\text { Water: } 6.1 \text { wt.-\% (waste wood); } \\
11.9 \text { wt.-\% (Bark) }\end{array}$ \\
\hline & \multirow[t]{2}{*}{ Empty fruit bunches } & Moisture: more than 50 wt.\%; \\
\hline & & Particle size: less than 1.0 mm; \\
\hline \multirow[t]{3}{*}{ Fluidized bed gasifier } & \multirow{3}{*}{$\begin{array}{l}\text { Pine, maple-oak } \\
\text { mixture, and } \\
\text { discarded seed corn }\end{array}$} & $\begin{array}{l}\text { Gasifying agent: Oxygen and } \\
\text { steam }\end{array}$ \\
\hline & & Temperature: $800^{\circ} \mathrm{C}$. \\
\hline & & Input fuel power: 800 kW \\
\hline \multirow{8}{*}{$\begin{array}{l}\text { Supercritical water } \\
\text { gasification }\end{array}$} & \multirow[t]{4}{*}{ Indole } & Reaction times: $3-80 \mathrm{~min}$ \\
\hline & & Temperature: 550 and $700^{\circ} \mathrm{C}$ \\
\hline & & $\begin{array}{l}\text { Initial indole concentration: } \\
0.2 \mathrm{~mol} / \mathrm{L}\end{array}$ \\
\hline & & Pressure: $30 \mathrm{MPa}$ \\
\hline & \multirow[t]{4}{*}{ Glycerol } & Temperature: $300-430^{\circ} \mathrm{C}$. \\
\hline & & Residence times: 5-120 min. \\
\hline & & $\begin{array}{l}\text { Feed concentrations: } 10,20 \text { e } \\
\qquad 30 \text { wt. } \%\end{array}$ \\
\hline & & Pressure: $30 \mathrm{MPa}$. \\
\hline \multirow[t]{4}{*}{ Steam gasification } & \multirow[t]{4}{*}{ Sugarcane bagasse } & Temperature: 800,900 and $1000^{\circ} \mathrm{C}$; \\
\hline & & Gasifying agent: $8 \mathrm{~g} / \mathrm{min}$ of steam; \\
\hline & & Tracer gas: $2.33 \mathrm{~g} / \mathrm{min}$ of nitrogen; \\
\hline & & $\begin{array}{c}\text { Sample: } 15 \mathrm{~g} \text { of sugarcane } \\
\text { bagasse. }\end{array}$ \\
\hline
\end{tabular}

Biomass not specified. Temperature: $800^{\circ} \mathrm{C}$ to $1200^{\circ} \mathrm{C}$.

Entrained-flow gasifier Raw bamboo; Torrefied bamboo; High-volatile bituminous coal

Forest residue

Atmospheric pressure gasifier and the pressurized gasifier.

Fixed bed reactor

\section{Crude glycerol with} olive kernel

Pine; Red oak; Horse manure; Cardboard
Gasification agent: Oxygen;

Sizes of the particles: $44-250 \mu \mathrm{m}$;

fuel temperature: $300 \mathrm{~K}$;

Pressure: $2 \mathrm{Mpa}$.

Moisture: 10 - 20\%;

Feedstock size: 20 - $80 \mathrm{~mm}$.

Temperature: $750-850^{\circ} \mathrm{C}$

Air ratios of $\lambda=0.2-0.4$

Temperature: $800^{\circ} \mathrm{C}$;

Moisture: 12.2 wt.\% (Pine), 14.8 wt.\% (Red oak) 18.33 wt.\% (Horse manure) 12.6 wt.\% (Cardboard)

\section{Results}

Reference

A lower amount of steam and the high

catalytic activity of the lignite caused a

better performance of the gasification reactor.

The reduction of particle size increases product gas yield in $+15.7 \%$.

The DFB gasifier is suitable for the conversion of fuels with higher loads of nitrogen.

The gasification efficiency decreases as the moisture content increases.

A high content of moisture and oxygen resulted in a low calorific value.

The gasification is most effective for feedstock with low nitrogen and moisture contents.

The yield of $\mathrm{CH}_{4}$ increased significantly as the indole concentration increased.

Hydrogen and carbon gasification efficiencies exhibited values up to $79 \%$ and $20 \%$, respectively.

The highest rate of coke formation occurred

in the temperature range of $350-370^{\circ} \mathrm{C}$ and long residence times.

The increase in reactor temperature resulted

in an increase in energy yield and apparent thermal efficiency.

The enhancement in syngas quality at the $1000^{\circ} \mathrm{C}$ case resulted in an increase of energy yield.

Higher gasification temperature leads to higher energy efficiencies of product gas and lower energy efficiencies of tar.

The carbon conversions of the three fuels are higher than $90 \%$.

In comparison with fuels and chemicals from conventional feedstocks, biomass based

fuels and chemicals are expensive.

$\mathrm{H}_{2}$ concentration increased from 19 to $33 \%$ $(\mathrm{v} / \mathrm{V})$ and the tar yield decreased from 19.5 to $2.4 \mathrm{wt} \%$ at conditions of $\mathrm{T}=850^{\circ} \mathrm{C}$ and $\lambda=0.4$.

The thermodynamic

efficiencies for the gasifier were found in the range of $81.7-84.6 \%$ 


\section{Table 1 Comparison of different types of biomass and gasification process (Continued)}

\begin{tabular}{ccc}
\hline Packed-bed reactor. & Mixture of & Temperature: 400 to $800^{\circ} \mathrm{C} ;$ \\
& $\begin{array}{c}\text { polypropylene and } \\
\text { poplar sawdust }\end{array}$ & Particle size: $2 \mathrm{~mm}$ (sawdust); \\
& $3 \mathrm{~mm}$ (polypropylene)
\end{tabular}

poplar sawdust

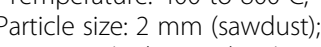

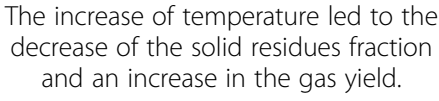

Optimum temperature: $700^{\circ} \mathrm{C}$ associated with the phase change of the water. This leads to an improvement in economic performance compared with a conventional gasification process [19]. These systems make use of the conditions of the critical point of water at $647.3 \mathrm{~K}$ and a pressure of $22.1 \mathrm{MPa}$ as a favorable environment for wet biomass gasification reactions [29].

\section{Plasma gasification}

Plasma is considered to be the fourth state of matter, consisting of a mixture of electrons, ions and neutral particles, although overall it is electrically neutral. The degree of ionization of a plasma is the proportion of atoms that have lost (or gained) electrons. Plasma technology involves the creation of a sustained electrical arc by the passage of electric current through a gas in a process referred to as electrical breakdown. Because of the electrical resistivity across the system, significant heat is generated, which strips away electrons from the gas molecules resulting in an ionized gas stream, or plasma $[15,34]$. Plasma gasification processes may reach temperatures from 2,000 to $30,000^{\circ} \mathrm{C}$ [29].

A general analysis of data compiled in Table 1 reveals that fluidized and fixed-bed reactors are more usual in gasification procedures. The variable more studied is temperature, where it is seen that at high temperature the energy production and the syngas quality increases, beyond that decrease the tars production. The particle size and the moisture have a significant influence in the gasification process, but if the particle size is reduced the syngas production increases and at high moisture contents the efficiency of gasification decrease.

\section{Pyrolysis}

Pyrolysis is an advanced thermal treatment that converts a material into a syngas at temperatures around $1000^{\circ} \mathrm{C}$ and in the absence of oxygen. Pyrolysis also can be described as the direct thermal decomposition of the organic matrix that could obtain solid, liquid and gas products [35-37]. Temperature is the most important factor for the product distribution of pyrolysis, most interesting range for the production of the pyrolysis products is between 625 and $775 \mathrm{~K}$. The charcoal yield decreases as the temperature increases. Yield of products resulting from biomass pyrolysis can be maximized as follows: charcoal (a low temperature, low heating rate process), liquid products (a low temperature, high heating rate, short gas residence time process), and fuel gas (a high temperature, low heating rate, long gas residence time process) $[8,38,39]$.

Lower process temperature and longer vapour residence times favour the production of charcoal. High temperature and longer residence time increase the biomass conversion

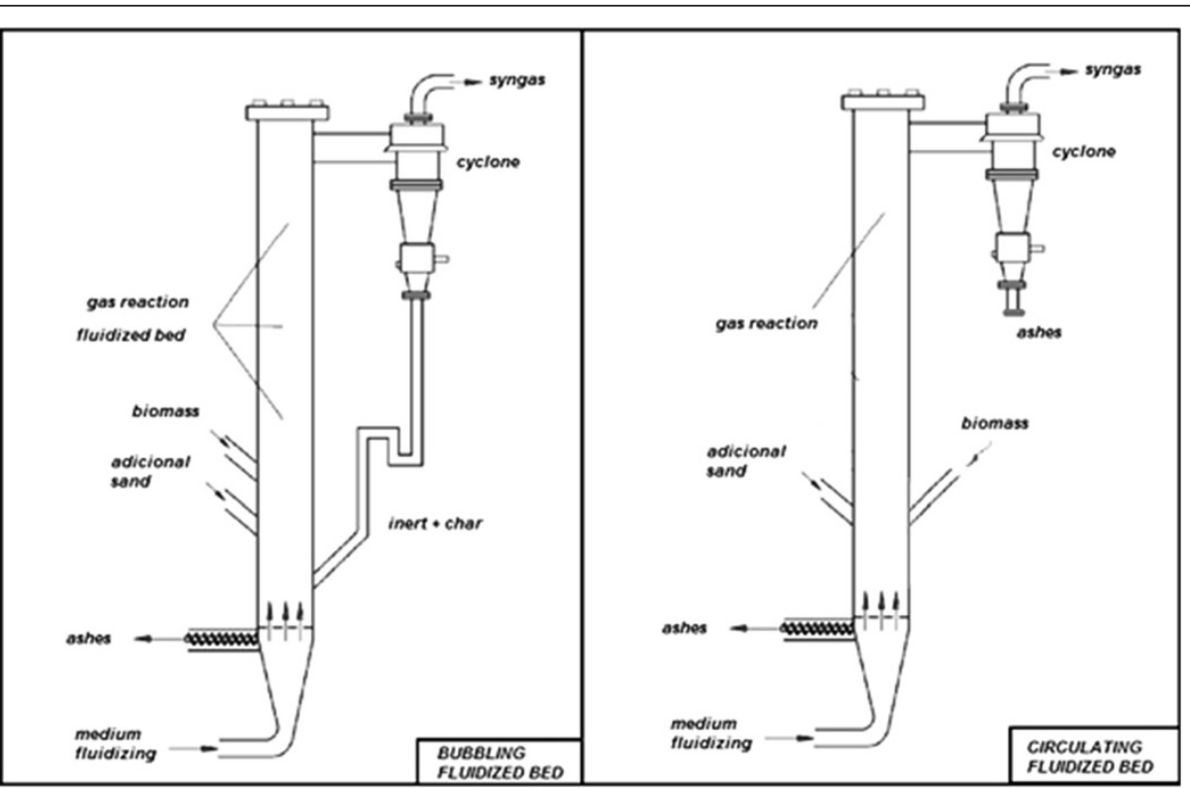

Figure 2 Schematic diagram of fluidized bed gasification technology taken from [30]. 


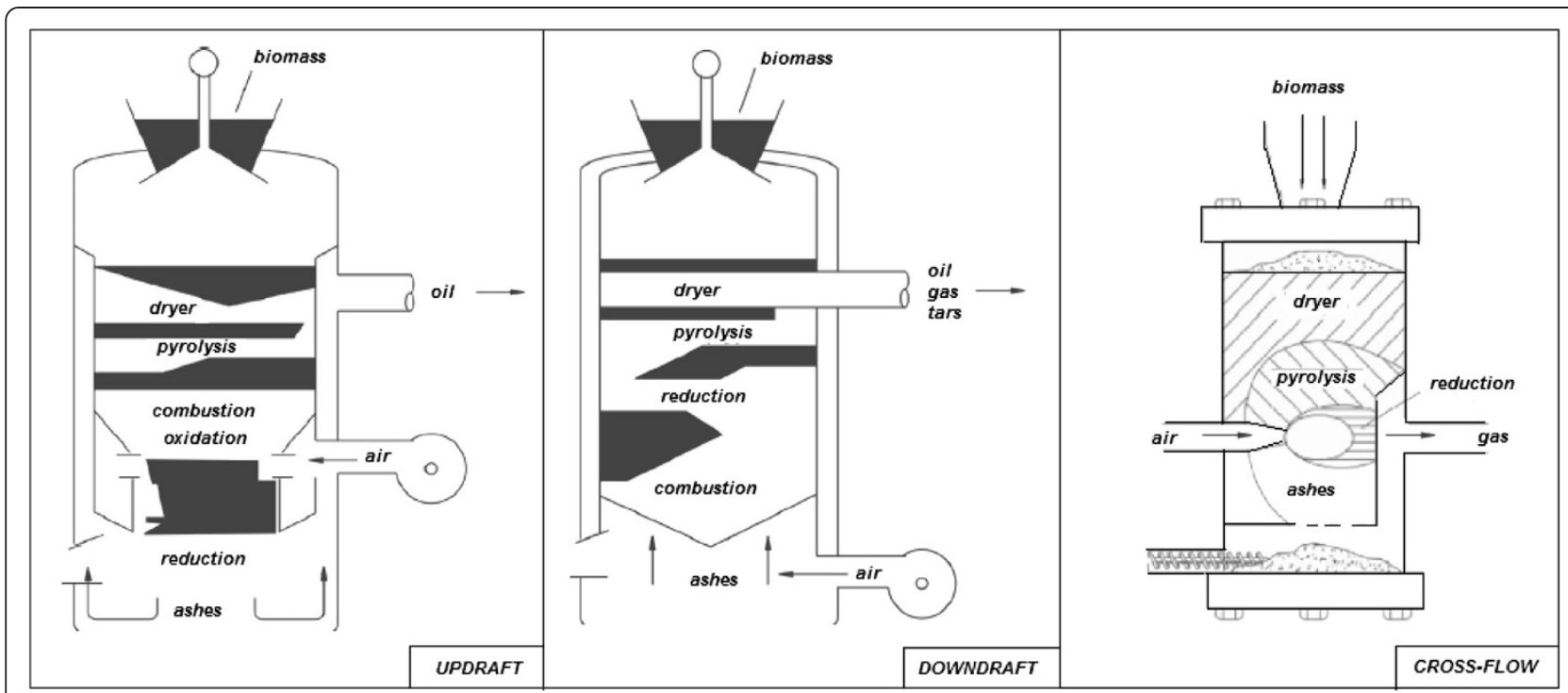

Figure 3 Schematic diagram of fixed bed gasifier technology taken from [32,33].

to gas and moderate temperature and short vapour residence time are optimum for producing liquids $[4,40]$. Short residence time pyrolysis of biomass at moderate temperatures has generally been used to obtain high yield of liquid products. For highly cellulosic biomass feedstocks, the liquid fraction usually contains acids, alcohols, aldehydes, ketones, esters, heterocyclic derivatives and phenolic compounds $[35,41,42]$.

The pyrolysis process for fuels and chemicals could be divided in: catalytic, fast and flash. The difference between them are the process conditions which involves the solid residence times, heating rate, particle size and temperature. These can be used for a commercial production of a wide range of fuels and chemical from biomass feedstocks $[38,43,44]$. To produce these syngas four different methods are applied, which are discussed below. A compilation among of different types of biomass and pyrolysis processes is described in Table 2.

\section{Slow pyrolysis}

Biomass is pyrolysed at slow heating rates $(5-7 \mathrm{~K} / \mathrm{min})$. This leads to less liquid and gaseous product and more of char production, at low temperature (675-775 K), and/or gas, at high temperature. Significant amount of work has been done on this process. The most used reactors in this process are fixed bed and tubular reactor [9].

\section{Fast pyrolysis}

Fast pyrolysis is a process in which a material, such as biomass, is rapidly heated to high temperatures in the absence of air (specifically oxygen). It involves fast heating of biomass but not as fast as flash pyrolysis. Heating rate is somewhere about $300^{\circ} \mathrm{C} / \mathrm{min}$. Generally, fast pyrolysis is used to obtain high-grade bio-oil. Fast pyrolysis is successful with different reactors configurations, some of them are fluidized-bed reactors, entrained flow reactor, wire mesh reactor, vacuum furnace reactor, vortex reactor, rotating reactor, circulating fluidized bed reactor. If the purpose was to maximize the yield of liquid products resulting from biomass pyrolysis, a low temperature, high heating rate, short gas residence time process would be required. If the purpose were to maximize the yield of fuel gas resulting from biomass pyrolysis, a high temperature, low heating rate, long gas residence time process would be preferred [9,53-55].

\section{Flash pyrolysis}

Flash pyrolysis is the process in which the reaction time is of only several seconds or even less. The heating rate is very high. This requires special reactor configuration in which biomass residence times are only of few seconds. Two of appropriate designs are entrained flow reactor and the fluidized-bed reactor. Flash pyrolysis of any kind of biomass requires rapid heating and therefore the particle size should be fairly small. Major problem of the present reactors for flash pyrolysis are the quality and the stability of the produced oil, strongly affected by char/ash content of bio-oil. Besides the known problems concerning solid particles in the bio-oil, char fines will catalyze repolymerization reactions inside the oil resulting in a higher viscosity. Flash pyrolysis is of following types: flash hydro-pyrolysis is flash pyrolysis done in hydrogen atmosphere, it is carried out at a pressure up to 20Mpa; rapid thermal process is a particular heat transfer process with very short heat residence times 
Table 2 Comparison of different types of biomass and pyrolysis process

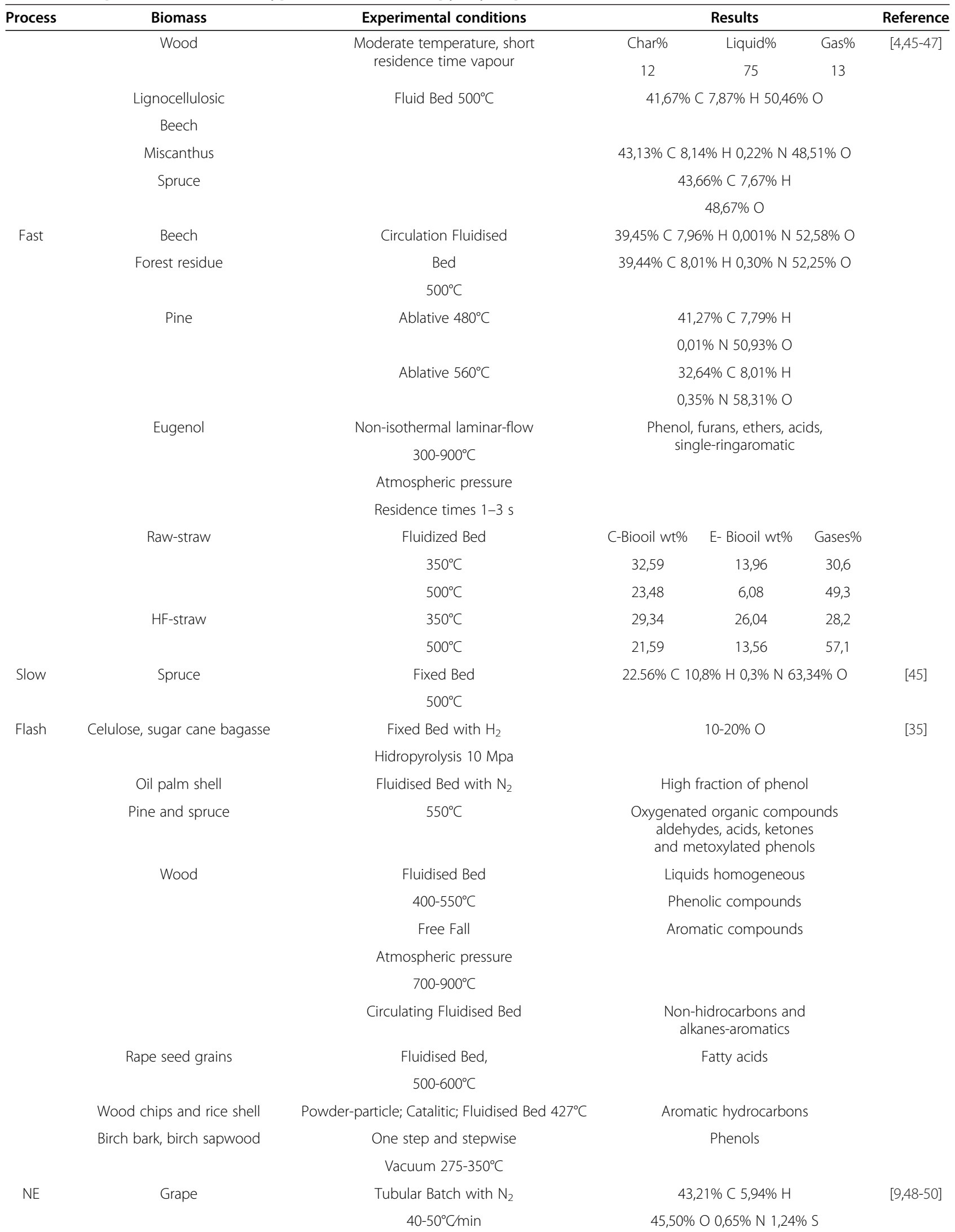


Table 2 Comparison of different types of biomass and pyrolysis process (Continued)

\begin{tabular}{|c|c|c|c|c|c|}
\hline Neem Seed & Semi-batch & \multirow{2}{*}{\multicolumn{3}{|c|}{$\begin{array}{l}\text { 38\% oil, large pore size, } \\
\text { high clorific value }\end{array}$}} & \\
\hline & $400-500^{\circ} \mathrm{C} 20^{\circ} \mathrm{C} / \mathrm{min}$ & & & & \\
\hline \multirow[t]{2}{*}{ Palm seed } & & \multicolumn{3}{|c|}{$45,3 \%$ C, 5,6\% H, 1\% N, } & \\
\hline & $200-450^{\circ} \mathrm{C}$ & \multicolumn{3}{|c|}{$0,8 \%$ S, 47,2\% O } & \\
\hline \multirow[t]{2}{*}{ Palm leaf } & & \multicolumn{3}{|c|}{$49,4 \% \mathrm{C}, 5,8 \% \mathrm{H}, 1,3 \% \mathrm{~N}$} & \\
\hline & & \multicolumn{3}{|c|}{$1,3 \% \mathrm{~S}, 42,3 \% \mathrm{O}$} & \\
\hline \multirow[t]{2}{*}{ Palm leaf stem } & & \multicolumn{3}{|c|}{$36,1 \% \mathrm{C}, 5,2 \% \mathrm{H}, 0,7 \% \mathrm{~N}$} & \\
\hline & & \multicolumn{3}{|c|}{$0,7 \% \mathrm{~S}, 57,2 \% \mathrm{O}$} & \\
\hline \multirow[t]{2}{*}{ Palm bituminous coal } & & \multicolumn{3}{|c|}{$73,1 \% \mathrm{C}, 5,5 \% \mathrm{H}, 1,4 \% \mathrm{~N}$} & \\
\hline & & \multicolumn{3}{|c|}{$1,7 \% \mathrm{~S}, 8,7 \% \mathrm{O}$} & \\
\hline \multirow[t]{7}{*}{ Wood } & $400^{\circ} \mathrm{C}$ & Char\% & Liquid\% & Gases\% & \\
\hline & & 24,1 & 65,5 & 10,2 & \\
\hline & $450^{\circ} \mathrm{C}$ & 21,4 & 65,7 & 11,1 & \\
\hline & $500^{\circ} \mathrm{C}$ & 18,9 & 66 & 14,6 & \\
\hline & $550^{\circ} \mathrm{C}$ & 17,3 & 67 & 14,9 & \\
\hline & $550^{\circ} \mathrm{C}$ & 16,7 & 67,8 & 15,7 & \\
\hline & $550^{\circ} \mathrm{C}$ & 17,1 & 66,2 & 15,2 & \\
\hline \multirow[t]{3}{*}{ Esparto grass } & Oxidative pyrolysis & \multicolumn{3}{|c|}{$0,50 \% \mathrm{~N}, 38,16 \% \mathrm{C}$} & \\
\hline & inert atmosphere & & & & \\
\hline & $25-650^{\circ} \mathrm{C}$ & & $-1,55,94 \%$ & & \\
\hline \multirow[t]{2}{*}{ Straw } & & \multicolumn{3}{|c|}{$0,21 \% \mathrm{~N}, 42,93 \% \mathrm{C}$} & {$[51]$} \\
\hline & & \multicolumn{3}{|c|}{$6,16 \% \mathrm{H}, 50,70 \% \mathrm{O}$} & \\
\hline \multirow[t]{2}{*}{ Posidonea Oceanic seaweed } & & \multicolumn{3}{|c|}{$0,71 \%$ N, 34,85\% C, } & \\
\hline & & \multicolumn{3}{|c|}{$4,54 \% \mathrm{H}, 0,62 \% \mathrm{~S}, 59,28 \% \mathrm{O}$} & \\
\hline \multirow[t]{2}{*}{ agricultural urban pruning waste } & & \multicolumn{3}{|c|}{$2,09 \%$ N, 48,06\% C, } & \\
\hline & & \multicolumn{3}{|c|}{$5,81 \% \mathrm{H}, 44,04 \% \mathrm{O}$} & \\
\hline \multirow[t]{2}{*}{ waste of forest pruning } & & \multicolumn{3}{|c|}{$0,65 \% \mathrm{~N}, 40,12 \% \mathrm{C}$} & \\
\hline & & \multicolumn{3}{|c|}{$5,44 \% \mathrm{H}, 53,79 \% \mathrm{O}$} & \\
\hline \multirow[t]{3}{*}{ Xylan } & Steam pyrolysis; $5 \times 10^{5} \mathrm{~Pa}$ & Char\% & Liquid\% & Gases\% & {$[52]$} \\
\hline & $703^{\circ} \mathrm{C}$ & 29,7 & 53,3 & 16,9 & \\
\hline & $873^{\circ} \mathrm{C}$ & 22,4 & 53,2 & 24,4 & \\
\hline Celulose & $703^{\circ} \mathrm{C}$ & 21 & 70,4 & 8,6 & \\
\hline & $873^{\circ} \mathrm{C}$ & 17,5 & 68,7 & 13,8 & \\
\hline Lignin & $703^{\circ} \mathrm{C}$ & 55,9 & 40,4 & 3,7 & \\
\hline & $873^{\circ} \mathrm{C}$ & 48,5 & 40 & 11,5 & \\
\hline
\end{tabular}

(between $30 \mathrm{~ms}$ and $1.5 \mathrm{~s}$ ). It is done at temperatures between 400 and $9501 \mathrm{C}$; rapid de-polymerization and cracking of feed stocks takes place; rapid heating eliminates the side reactions whereby giving products with comparable viscosity to diesel oil; solar flash pyrolysis concentrated solar radiation can be used to perform flash pyrolysis; vacuum flash pyrolysis the process is done under vacuum, the vacuum facilitates the removal of the condensable products from the hot reaction zone [56-58].

\section{Catalytic biomass pyrolysis}

From literature it was seen that liquids obtained from biomass by slow, flash or fast pyrolysis process, could not be directly used as transportation fuel. This oil needs to be upgraded as they have high oxygen and water content. These oils are also found to be less stable and less miscible in conventional fuels. Catalytic biomass pyrolysis is introduced to improve the quality of the oil produced $[38,59,60]$. 
Table 3 Recent technologies in gasification and pyrolysis process

\begin{tabular}{|c|c|c|c|c|}
\hline & Process & Patent & Registration number & Reference \\
\hline \multirow[t]{8}{*}{ Gasification } & Gas/shaft process & $\begin{array}{l}\text { Method and apparatus for coproduction } \\
\text { of pig iron and high quality syngas. }\end{array}$ & WO 2012/018394 A3 & {$[65]$} \\
\hline & N.E. & $\begin{array}{l}\text { Nanoparticle catalyst and method of using } \\
\text { the same for biomass gasification. }\end{array}$ & US 2011/0315931 A1 & {$[66]$} \\
\hline & Fischer-Tropsch reactor & Method of puryfing a gas. & US 2012/0202897 A1 & {$[67]$} \\
\hline & Fluidized bed gasifier & Pretreatment of biomass feed for gasification. & US 2012/0266531 A1 & [61] \\
\hline & Mixed flow & $\begin{array}{l}\text { Method and device for mixed flow type } \\
\text { gasification of biomass. }\end{array}$ & US 2012/159469 A1 & {$[68]$} \\
\hline & Fluidized bed and downstream edge & $\begin{array}{l}\text { Method for producing production gas } \\
\text { and apparatus using same. }\end{array}$ & US 2012/176611 A1 & [62] \\
\hline & N.E. & $\begin{array}{l}\text { Ammonia production by integrated } \\
\text { intencified process. }\end{array}$ & WO 2012/025767 A3 & [69] \\
\hline & Combined reactor & $\begin{array}{l}\text { A processes and a system for the gasification } \\
\text { and/or combustion of biomass and/or coal with } \\
\text { and at least partial carbon dioxide separation. }\end{array}$ & WO 2012/103997 A1 & [70] \\
\hline \multirow[t]{8}{*}{ Pyrolysis } & $\mathrm{NE}$ & $\begin{array}{c}\text { Production of stable biomass pyrolysis oils using } \\
\text { fractional catalytic pyrolysis }\end{array}$ & US 2010/0212215 A1 & [71] \\
\hline & $\begin{array}{l}\text { Producing of biofuel by fast pyrolysis of } \\
\text { organic material, using a system of three } \\
\text { interconnected serial fluidized bed reactors }\end{array}$ & $\begin{array}{l}\text { Equipment and a method for generating biofuel } \\
\text { based on rapid pyrolysis biomass }\end{array}$ & US 2011/0219680 A1 & [72] \\
\hline & $\begin{array}{l}\text { Producing substitute natural gas (hydrocarbons) } \\
\text { from forestry residues by hydropyrolysis }\end{array}$ & Sorption enhanced methanation of biomass & US 2013/0017460 A1 & [73] \\
\hline & $\mathrm{NE}$ & $\begin{array}{l}\text { Method and apparatus for pyrolysis and } \\
\text { gasification of biomass }\end{array}$ & US 2013/0125465 A1 & [74] \\
\hline & $\begin{array}{l}\text { Reactor with rotational chamber for pyrolysis } \\
\text { of biomass to conversion in energy }\end{array}$ & Reactor for pyrolysis of biomass & WO 2011/034409 A1 & [75] \\
\hline & $\mathrm{NE}$ & $\begin{array}{c}\text { Process for catalytic hydrotratament of a } \\
\text { pyrolysis oil }\end{array}$ & WO 2011/064172 A1 & [63] \\
\hline & $\begin{array}{l}\text { Pyrolytic conversion of biomass materials into } \\
\text { stable fuels and other usable products }\end{array}$ & Production of pyrolysis oil & WO 2011/103313 A2 & {$[76]$} \\
\hline & $\begin{array}{l}\text { Effective pyrolysis of a biomass utilizing rapid } \\
\text { heat transfer from a solid heat carrier or catalyst }\end{array}$ & $\begin{array}{l}\text { Method and apparatus for pyrolysis } \\
\text { of a biomass }\end{array}$ & WO 2012/012191 A1 & [64] \\
\hline
\end{tabular}

\section{Technologies}

Table 3 shows the latest technologies that involves the production of syngas and biofuels by gasification and pyrolysis processes from biomass. The gasification process by fluidized-bed reactor is the most common among registered technologies, as showed in Table 3. The registered patents, US 2012/0266531 A1 [61] e US 2012/176611 A1 [62], use this process to make a pretreatment of biomass and to produce the syngas. Referring the technologies for pyrolysis, it is found registers for catalitic pyrolysis, fast pyrolysis e hidropyrolysis. Catalitic pyrolysis is the most used technology, where the registered patents WO 2011/064172 A1 [63] used catalysts to make an oil, whereas WO 2012/012191 A1 [64] used the effective pyrolysis of biomass to produce biofuels through fast thermal exchange.

\section{Competing interests}

The authors declare that they have no competing interests.

\section{Authors' contributions}

All authors contributed equally in this work. All authors read and approved the final manuscript

\section{Acknowledgements}

The authors thank CAPES for scholarships.

Received: 11 September 2013 Accepted: 17 November 2013

Published: 20 November 2013

\section{References}

1. Shen Y, Yoshikawa K: Recent progresses in catalytic tar elimination during biomass gasification or pyrolysis: a review. Renew Sustain Energy Rev 2013, 21:371-392.

2. Huynh CV, Kong S: Performance characteristics of a pilot-scale biomass gasifier using oxygen-enriched air and steam. Fuel 2013, 103:987-996.

3. Higman C, van der Burgt M: Gasification, Elsevier science. 2dth edition. Burlington, MA, USA: Gulf Professional Publishing; 2003.

4. Bridgwater $A V$ : Renewable fuels and chemicals by thermal processing of biomass. Chem Eng J 2003, 91:87-102.

5. Yang J, Blanchette D, De CB, Roy C: Modelling, scale-up and demonstration of a vacuum pyrolysis reactor. In Thermochemical biomass conversion, Volume 107. Edited by Bridgwater AV. Oxford, UK: Blackwell Scientific Publications; 2001:1296-1311. 
6. Lupa CJ, Wylie SR, Shaw A, Al-Shamma'a A, Sweetman AJ, Herbert BMJ: Experimental analysis of biomass pyrolysis using microwave-induced plasma. Fuel Process Technol 2012, 97:79-84.

7. Neves D, Thunmanb H, Matos A, Tarelhoa L, Gómez-Bareac A: Characterization and prediction of biomass pyrolysis products. Progress Energy Combustion Sci-ence 2011, 37:611-630.

8. Mohan D, Pittman CU Jr, Steele PH: Pyrolysis of wood/biomass for bio-oil: acritical review. J Energy Fuels 2006, 20:848-889.

9. Goyal HB, Seal D, Saxena RC: Bio-fuels from thermochemical conversion of renewable resources: a review. Renew Sustain Energy Rev 2008, 12:504-517.

10. Basu P: Biomass gasification and pyrolysis: practical design and theory. 1st edition. Burlington, USA: Elsevier Inc; 2010.

11. Hindsgaul C, Schramm J, Gratz L, Henriksen U, Dall Bentzen J: Physical and chemical characterization of particles in producer gas from wood chips. Bioresour Technol 2000, 73:147-155.

12. Barman NS, Ghosh S: Gasification of biomass in a fixed bed downdraft gasifier: a realistic model including tar. Bioresour Technol 2012, 107:505-511.

13. Brown RC: Biorenewable resources: engineering new products from agriculture. lowa State Press 2003

14. Wilk V, Hofbauer $\mathrm{H}$ : Conversion of fuel nitrogen in a dual fluidized bed steam gasifier. Fuel 2013, 106:793-801.

15. Kalinci Y, Hepbasli A, Dincer I: Exergoeconomic analysis and performance assessment of hydrogen and power production using different gasification systems. Fuel 2012, 102:187-198.

16. Swanson R, Platon A, Satrio J, Brown RC: Techno-economic analysis of biomass-to-liquids production based on gasification. Fuel 2010, 89:11-19.

17. Kern S, Pfeifer C, Hofbauer H: Gasification of lignite in a dual fluidized bed gasifier: Influence of bed material particle size and the amount of steam. Fuel Process Technol 2013, 111:1-13.

18. Mohammed MAA, Salmiaton A, Azlina WAKG W, Amran MSM: Gasification of oil palm empty fruit bunches: a characterization and kinetic study. Bioresour Technol 2012, 110:628-636.

19. Guo Y, Wang S, Huelsman CM, Savage PE: Products, pathways, and kinetics for reactions of indole under supercritical water gasification conditions. J Supercrit Fluids 2013, 73:161-170.

20. Müller JB, Vogel F: Tar and coke formation during hydrothermal processing of glycerol and glucose. Influence of temperature, residence time and feed concentration. J Supercrit Fluids 2012, 70:126-136.

21. Ahmed II, Gupta AK: Sugarcane bagasse gasification: global reaction mechanism of syngas evolution. App/ Energy 2012, 91:75-81.

22. Zhang $Y$, Li B, Li H, Zhang B: Exergy analysis of biomass utilization via steam gasification and partial oxidation. Thermochim Acta 2012, 538:21-28.

23. Chen W, Chen C, Hung C, Shen C, Hsu H: A comparison of gasification phenomena among raw biomass, torrefied biomass and coal in an entrained-flow reactor. Appl Energy 2013, xxx:xxx.

24. Sarkar S, Kumar A, Sultana A: Biofuels and biochemicals production from forest biomass in western Canada. Energy 2011, 36:6251-6262.

25. Skoulou VK, Zabaniotou AA: Co-gasification of crude glycerol with lignocellulosic biomass for enhanced syngas production. J Anal Appl Pyrolysis 2013, 99:110-116.

26. Lee $U$, Balu $E$, Chung JN: An experimental evaluation of an integrated biomass gasification and power generation system for distributed power applications. App/ Energy 2013, 101:699-708.

27. MENG Q, Chen X, Zhuang Y, Liang C: Effect of temperature on controlled air oxidation of plastic and biomass in a packed-bed reactor. Chem Eng Technol 2013, 36(2):220-227.

28. Rapagna S, Jand N, Kiennemann A, Foscolo PU: Steam-gasification of biomass in a fluidized-bed of olivine particles. Biomass Bioenergy 2000, 19:187-197

29. Ruiz JA: Biomass gasification for electricity generation: review of current technology barriers. Renew Sustain Energy Rev 2013, 18:174-183.

30. Olofsson I, Nordin A, Sönderlimd U: Initial Review and Evaluation of Process Technologies and Systems Suitable for Cost-Efficient Medium-Scale Gasification for Biomass to Liquid Fuels. 2005. ISSN 1653-0551 ETPC Report 05-02, Energy Technology \& Thermal Process Chemistry, University of Umeå, Sweden.

31. Gómez-Barea A, Ollero P, Leckner B: Optimization of char and tar conversion in fluidized bed biomass gasifiers. Fuel 2013, 103:42-52.

32. Mckendry P: Energy production from biomass (part 3): GasificationTechnologies. Bioresour Technol 2002, 83(1):55-63

33. Battacharya SC, Siddique AH, Pham HL: A study on wood gasification for Low-Tar Gas production. Energy 1999, 24:285-296.
34. Gomez E, Rani DA, Cheeseman CR, Deegan D, Wise M, Boccaccini AR: Thermal plasma technology for the treatment of wastes: a critical review. J Hazard Mater 2009, 161:614-626.

35. Yaman S: Pyrolysis of biomass to produce fuels and chemical feedstocks. Energy Convers Manag 2004, 45:651-671.

36. Raveendran K, Ganesh A: Flash pyrolysis of sunflower oil cake for production of liquid fuels. Fuel 1996, 75:1715-1720.

37. MEIER D, FAIX O: State of the art of applied fast pyrolysis of lignocellulosic materials-a review. Biosource Technol 1999, 68(1):71-77.

38. Balat M, Balat M, Kırtay E, Balat H: Main routes for the thermo-conversion of biomass into fuels and chemicals. Part 1: pyrolysis systems. Energy Convers Manag 2009, 50:3147-3157.

39. Abella L, Nanbu S, Fukuda K: A theoretical study on levoglucosan pyrolysis reactions yielding aldehydes and a ketone in biomass. Mem Fac Eng, Kyushu Univ 2007, 67:67-74.

40. Diebold JP: A review of the chemical and physical mechanisms of the storage stability of fast pyrolysis bio-oils. In Fast pyrolysis of biomass: a handbook, Volume 2. Edited by Bridgwater AV. Newbury, UK: CPL Press; 2002:243-292.

41. Gullu D, Demirbas A: Biomass to methanol via pyrolysis process. Energy Conv Manage 2001, 42:1349-1356.

42. Fisher $T$, Hajaligol M, Waymack B, Kellogg D: Pyrolysis behavior and kinetics of biomass derived materials. J Anal Appl Pyrol 2002, 62:331-349.

43. Zhang $\mathrm{O}$, Chang J, Wang T, Xu Y: Review of biomass pyrolysis oil properties and upgrading research. Energy Convers Manage 2007, 48:87-92.

44. Bakis R: Alternative electricity generation opportunities. Energy Source Part A 2008, 30:141-148.

45. Blin J, Volle G, Girard P, Bridgwater T, Meier D: Biodegrability of biomass pyrolysis oils: comparison to conventional petroleum fuels and alternatives fuels in current use. Fuel 2007, 86:2679-2686.

46. Ledesma EB, Campos C, Cranmer DJ, Foytik BL, Ton MN, Dixon EA, Chirino C, Batamo S, Roy P: Vapour -phase cracking of eugenol: distribuition of tar products as fuctions of temperature and residence time. Energy and Fuels 2013, 27:868-878

47. Eom I, Kim J, Lee S, Cho T, Yeo H, Choi J: Comparison of pyrolytic products produced from inorganic-rich and demineralized rice straw (oryza sativa L.) by fluidized bed pyrolyzer for future biorefinery approach. Bioresour Technol 2013, 128:664-672.

48. Marculescu C, Ciuta S: Wine industry waste termal processing for derived fuel properties improvement. Renew Energy 2013, 57:645-652.

49. Nayan NK, Kumar S, Singh RK: Production of the liquid fuel by thermal pyrolysis of neem seed. Fuel 2013, 103:437-443.

50. Sait HH, Hussuain A, Salema AA, Ani FN: Pyrolysis and combustion kinetics of date palm biomass using thermogravimetric analysis. Bioresour Technol 2012, 118:382-389.

51. Conesa JA, Domene A: Biomasses pyrolysis and combustion kinetics through n-th order parallel reactions. Thermochimical Acta 2011, 523:116-181.

52. Giudicianni P, Cardone G, Ragucci R: Cellulose, hemicellulose and lignin slow steam pyrolysis: thermal decomposition of biomass components mixtures. J Anal Apllied Pyrolysis 2013:213-222.

53. Luo Z, Wang S, Liao Y, Zhou J, Gu Y, Cen K: Research on biomass fast pyrolysis for liquid fuel. Biomass Bioenergy 2004, 26:455-462.

54. Onay O, Beis SH, Kockar OM: Fast pyrolysis of rape seed in well-swept fixed bed reactor. J Anal Appl Pyrolysis 2001, 58-59:995-1007.

55. Onay O, Kockar OM: Technical note: slow, fast and flash pyrolysis of rape seed. Renew Energy 2003, 28:2417-2433.

56. Gercel HF: Production and characterization of pyrolysis liquids from sunflower pressed bagasse. Bioresource Technol 2002, 85:113-117.

57. Funino J, Yamaji K, Yamameto H: Biomass-balance table for evaluating bioenergy resources. Appl Energy 1999, 63:75-89.

58. Lede J, Bouton O: Flash pyrolysis of biomass submitted to a concentrated radiation. Application to the study of the primary steps of cellulose thermal decomposition. In Division of fuel chemistry; reprints of symposia vol. 44(2), 217th ACS meeting, 21-25 march. Anaheim, USA; 1999.

59. Pattiya A, Titiloye JO, Bridgwater AV: Catalytic pyrolysis of cassava rhizome In Proceedings of 2nd joint international conference on sustainable energy and environment technology and policy innovations - SEE 2006. Bangkok, Thailand; 2006

60. Pattiya A, Titiloye JO, Bridgwater AV: Fast pyrolysis of cassava rhizome in the presence of catalysts. J Anal Appl Pyrolysis 2008, 81:72-79.

61. Hitchingham Jacqueline R, White Lloyd R: Pretreatment of biomass feed for gasification. United States Patent Application 2012/0266531 A1; 2012. 
62. Shigeru M: Surface inspection method and surface inspection apparatus. US United States Patent Application 2012/176611 A1; 2012.

63. Hogendoorn J, Kersten S, Meesala L, De Miguel F: Process for catalytic hydrotreatment of a pyrolysis oil. WO Patent Application 2011/064172 A1; 2011.

64. Bartek R, Cordle R: Method and apparatus for pyrolysis of a biomass. WO International Patent Application 2012/012191 A1: 2012

65. Huang X, Hwang J: Method and apparatus for coproduction of pig iron and high quality syngas. WO International Patent Application 2012/018394 A3; 2012.

66. Aradi AA, Roos JW, Tze-chi: Nanoparticle catalysts and method of using the same for biomass gasification. US United States Patent Application 2011/0315931 A1; 2011.

67. Keskinen Kari I, Koskinen, Jukka, Aittamaa, Juhani, Pettersson, Marianne: Method of purifying a gas. US United States Patent Application 2012/0202897 A1; 2012.

68. Xiangi P, Deren S, Chuangzhi W, Xiuli Y, Zhaoqiu Z: Procédé et dispositif pour la gazéification de type à écoulements mélangés d'une biomasse. US United States Patent Application 2012/159469 A1; 2012

69. Sascha AC, Bradford SF: Method and apparatus for sealing a wellbore. WO International Patent Application 2012/025767 A3: WO International Patent Application 2012/025767 A3; 2013.

70. Paul S: Procédé et système pour la gazéification et/ou la combustion de biomasse et/ou de charbon avec une séparation de dioxyde de Carbone au moins partielle. WO International Patent Application 2012/103997 A1; 2012.

71. Foster AA: Production of stable biomass pyrolysis oils using fractional catalytic pyrolysis. United States Patent Application 2010/0212215 A1; 2010.

72. Igor WF: Equipment and method for generating biofuel based on rapid pyrolysis of biomass. US United States Patent Application 2011/0219680 A1; 2011.

73. Bowie GK MB, Brian GS, Edson NG: Sorption enhanced methanation of biomass. US United States Patent Application 2013/0017460 A1; 2013.

74. Tang H, Zhang Y, Chen Y: Method and apparatus for pyrolysis and gasification of biomass. US United States Patent Application 2013/0125465 A1; 2013.

75. Merola R: Reactor for pyrolysis of biomass. WO International Patent Application 2011/034409 A1; 2011.

76. Agblevor F: Production of pyrolysis oil. WO International Patent Application 2011/103313 A2; 2011

doi:10.1186/2043-7129-1-22

Cite this article as: Canabarro et al:: Thermochemical processes for biofuels production from biomass. Sustainable Chemical Processes 2013 1:22.

\section{Publish with ChemistryCentral and every scientist can read your work free of charge \\ "Open access provides opportunities to our colleagues in other parts of the globe, by allowing anyone to view the content free of charge." \\ W. Jeffery Hurst, The Hershey Company. \\ - available free of charge to the entire scientific community \\ - peer reviewed and published immediately upon acceptance \\ - cited in PubMed and archived on PubMed Centra \\ - yours - you keep the copyright \\ Submit your manuscript here: \\ http://www.chemistrycentral.com/manuscript/<smiles>c1ccccc1</smiles> \\ Chemistry Central}

